Maciej SZKODA, Grzegorz KACZOR, Magdalena SATORA

Cracow University of Technology (Politechnika Krakowska)

\title{
METHODOLOGY OF BUILDING THE STRATEGY OF MAINTENANCE OF RAIL VEHICLES WITH THE USE OF THE RAMS ANALYSIS IN THE AREA OF SAFETY
}

\section{Metodyka budowy strategii utrzymania kolejowych środków transportu z wykorzystaniem analizy RAMS w obszarze bezpieczeństwa}

\begin{abstract}
The paper discusses one of the most important stages in the developed methodology for building a strategy of maintenance of railway vehicles, which is the RAMS analysis (Reliability, Availability, Maintainability, Safety) in the area of safety. The paper presents the application of RAMS analysis in the construction process (development or change) of the maintenance strategy on the example of a $6 \mathrm{Dg}$ diesel locomotive. Based on the conducted research, it was found that this analysis enables proper classification of hazards, quantification of the frequency of occurrence of hazards and the adoption of the appropriate criteria for risk assessment of the created strategy.
\end{abstract}

Keywords: RAMS analysis, railway vehicles, maintenance system

Streszczenie: W pracy omówiono jeden z najistotniejszych etapów w opracowanej metodyce budowy strategii utrzymania kolejowych środków transportu jakim jest analiza RAMS (Reliability, Availability, Maintainability, Safety) $w$ obszarze bezpieczeństwa. W pracy przedstawiono zastosowanie analizy RAMS w procesie budowy (opracowania lub zmiany) strategii utrzymania na przyktadzie lokomotywy spalinowej typu 6Dg. Na podstawie przeprowadzonych badań stwierdzono, że analiza ta umożliwia właściwa klasyfikację zagrożeń, kwantyfikację częstości wystąpienia zagrożeń, a także przyjęcie właściwych kryteriów w ocenie ryzyka budowanej strategii.

Słowa kluczowe: analiza RAMS, kolejowe środki transportu, system utrzymania 


\section{Introduction}

The research and development work to build a maintenance strategy [1, 8-10] done in the Institute of Rail Vehicles, Cracow University of Technology proves that the maintenance costs constitute up to $36.4 \%$ of the Life Cycle Costs (LCC) of rail vehicles and are the second, after the costs of energy or fuel consumption, dominating cost category. In 25 years of operation, these costs may reach between PLN 2.1 million for shunting locomotives and PLN 13.8 million for electric multiple units. In recent years, projects relating to a change to the strategies applied to date for the maintenance of means of transport (electric and diesel locomotives, freight and passenger cars and special vehicles) are very often undertaken by rail transport companies. They are oriented primarily at maintenance cost savings but often leave out an assessment of the risk of hazards and the impact of the proposed changes on the rail system safety. Changes of various kinds in the area of maintenance may contribute to a worsening of the technical condition of vehicles and constitute a potential source of hazards to the railway system.

\section{Methodology of building the strategy of maintenance of rail vehicles}

In response to the high demand on the part of rail companies, based on an analysis of specialist writings and the experience acquired in the performance of research and development work, an attempt was made to develop a methodology of building the strategy of maintenance of rail vehicles taking account of the efficiency of the proposed solutions and their impact on the rail system safety [810]. The procedure in the methodology which was developed is presented in fig. 1.

One of the most important stages in the methodology is the RAMS analysis in the area of safety whose theoretical foundations are described in the standard PNEN 50126:2018 Railway applications - the Specification and Demonstration of Reliability, Availability, Maintainability and Safety [11, 18, 19]. Safety means the absence of an unacceptable risk which describes the frequency of accidents and incidents leading to a failure (caused by a hazard) and the gravity thereof [14]. According to the definition presented in the standard PN-EN 50126, safety means the absence of catastrophic consequences to the user and the environment. 


\section{Characteristics used in the RAMS analysis in the area of safety}

The assessment of safety in railway transport is a very complex issue. The prevailing formal document in the assessment of safety in railway transport is Directive 2004/49/EC of the European Parliament and of the Council of 29 April 2004 on safety on the Community railways. The current version was amended by Directive 2008/110/EC of the European Parliament and of the Council of 16 December 2008, Commission Directive 2014/88/EU of 9 July 2014, Directive (EU) 2016/798 of the European Parliament and of the Council of 11 May 2016. Since the entry into force of the Directive, matters relating to safety have been institutionalised at the European Union's level through the introduction of common objectives, requirements and safety indicators in connection with the requirements contained in the Technical Interoperability Standards [3].

The Common Safety Indicators (CSI) concern statistical data relating to accidents in railway transport, consequences of such accidents, technical safety of the railway infrastructure and safety management. The overall level of safety in railway transport is characterised by two measures:

- measure of accidents defined as the number of major accidents in operational work [number of accidents /millions of train $/ \mathrm{km}$ ],

- measure of accident gravity defined as the number of victims of major accidents expressed in FWSI (arbitrary measure of the number of victims in which the fatalities have the weight of 1 , and the seriously injured ones the weight of 0.1) in operational work [FWSI/ millions of train/ $\mathrm{km}$ ] [2].

In national legislation, these have been defined in the Regulation of the Minister of Infrastructure and Development of 21 July 2015 on Common Safety Indicators. The Regulation sets the indicators which the President of the Railway Transport Office places in the annual safety report based on reports received from railway managers and carriers. These indicators concern:

- basic railway transport activities,

- railway incidents and their consequences,

- suicides,

- hazardous goods,

- occurrences preceding accidents,

- economic effects of accidents received from infrastructure managers and railway carriers,

- technical safety of the railway infrastructure. 


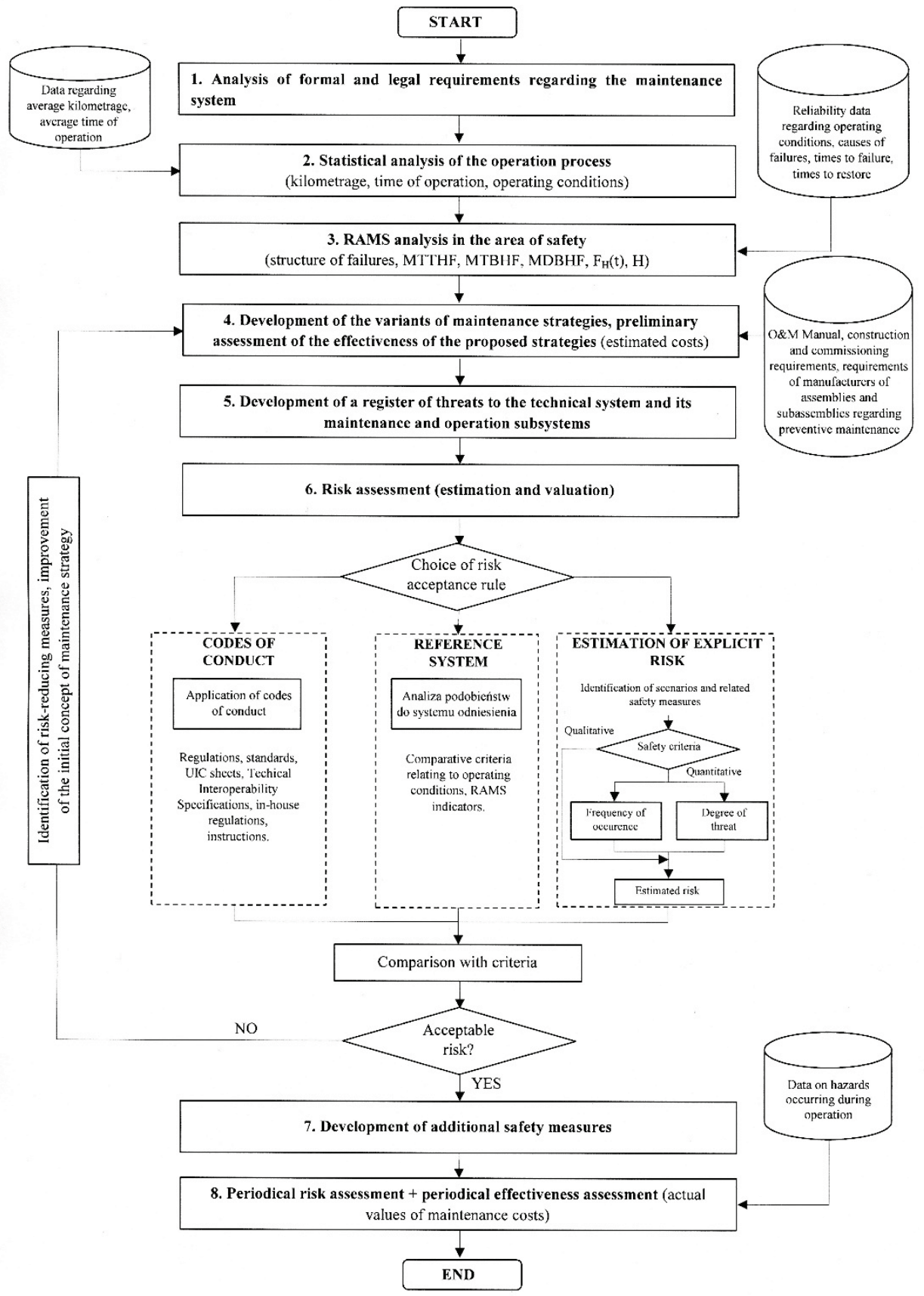

Fig. 1. Algorithm for the building (developing a new or changing the existing) strategy of maintenance of rail vehicles. 
The list of indicators included in an annex to Directive 2004/49/EC is obligatory but not exhaustive.

In the assessment of the safety of rail vehicles, it is necessary to define the indicators concerning two areas: failures and hazardousness - a condition which may generate losses. In this regard, the indicators defined in points a $\div \mathrm{d}$ based on safety standards: PN-EN 61508, PN-EN 50129, PN-EN 50126 [11-13] may be helpful and specialist writings on the assessment of reliability, availability, maintainability and safety $[4,5,7,15,16]$ concerning the probability of occurrence of failures, including in particular the so-called hazardous failures and the consequences thereof.

\section{a) Probability of a Failure $F_{H}(t)$}

$F_{H}(t)$ is the probability that the vehicle will fail no later than at the moment $\mathrm{t}$ and is expressed in the probability density function of time to failure $f_{H}(t)$ :

$$
F_{H}(t)=\int_{0}^{t} f_{H}(x) d x t \geq 0
$$

\section{b) Mean Time to Hazardous Failure MTTHF}

$$
\text { MTTHF }=\int_{0}^{\infty} t \cdot f_{H}(t) d t
$$

symbols as above

\section{c) Mean Time Between Hazardous Failures $M T B H F$}

$$
M T B H F=\int_{0}^{\infty} t \cdot f_{B H}(t) d t
$$

where:

$f_{B H}(t)$ - probability density function of time between the (k-1) restoration and the failure numbered $\mathrm{k}$

Empirical estimate:

$$
M T B H F^{*}=\frac{1}{N(0)}\left(t_{H 1}^{(k)}+t_{H 2}^{(k)}+\cdots+t_{H N(0)}^{(k)}=\frac{1}{N(0)} \sum_{i=1}^{N(0)} t_{H i}^{(k)}\right.
$$

where:

$$
N(0) \quad-\text { number of examined vehicles, }
$$


$t_{H i}^{(k)} \quad-$ random performance of the working time of the vehicle after the (k-1) restoration until the failure numbered $k$.

If, in the formula above, instead of time, the total distance in a time range is covered $(0, t)$, we get the mean distance between hazardous failures $M D B H F$ expressed in the kilometres covered.

\section{d) Frequency of occurrence of a hazardous failure $\boldsymbol{H}$}

$$
H=\frac{n_{H}(t)}{T}
$$

where:

$n_{H}(t)$ - number of hazardous failures in a time range $(0, t)$,

$T$ - total time of vehicle operation in a time range $(0, t)$.

The above indicator is similar to the Probability of Failure per Hour (PFH) used to assess the Safety Integrity Level (SIL) for electronic railway control equipment and systems $[6,13,17]$.

\section{Example of the application of selected aspects of the RAMS analysis in the area of safety}

This chapter presents selected aspects of the application of the RAMS analysis in building the strategy of maintenance of rail vehicles based on the example of a 6Dg locomotive. The RAMS analysis in the area of safety included the following stages: failure analysis, identification of locomotive assemblies, subassemblies and elements which are relevant from the viewpoint of railway safety and the identification of durability and reliability characteristics which are the basis for assessing and appraising the risk.

\subsection{Operating surveys}

In the example under consideration, the RAMS analysis was based on the results of operating surveys of a selected sample of $756 \mathrm{Dg}$ locomotives operated by a railway carrier over a period of 15 months. This enabled an observation of the course of operation of locomotives in various conditions, thus generating reliable data for the reliability analysis. The reliability data were gathered in the carrier's 
IT system enabling precise recording of the Time to Failure (TTF) and the Time to Restore (TTR).

\subsection{Structure of failures of $6 \mathrm{Dg}$ locomotives}

During the period of operation under analysis, a total of 494 failures were recorded that is 6.6 [failures/ locomotive] on average. Based on the analysis, it was concluded that the most frequent failures recorded during operation included:

- failures of electric circuit elements, devices and equipment $-23.7 \%$,

- failures of the diesel engine $-16.8 \%$,

- failures of the vigilance devices $-11.3 \%$,

- failures caused by incorrect vehicle operation $-9.1 \%$,

- failures of batteries $-7.9 \%$.

Statistical data confirmed the regularity emphasised on writings in the subject that one of the most failing element of the system is a human (operator) who, through his errors, causes hazards to himself and the surroundings [20]. Failures caused by incorrect operation of the locomotive constitute $9.1 \%$ of all failures.

\subsection{RAMS indicators relating to safety}

From the viewpoint of safety assessment of the strategy of maintenance of a 6Dg locomotive, the most important were the indicators relating to material elements that is the locomotive's assemblies and subassemblies whose failures involve hazards to the reliability and railway safety (so-called hazardous failures). The analysis of the statistical data on the causes and types of hazardous failures of a $6 \mathrm{Dg}$ locomotive demonstrated that the following were the most hazard-relevant failures:

1. Running gear:

1.1. failures and wear of the wheel's outer contour $-3.6 \%$,

2. Brake system (pneumatic and mechanical parts):

2.1. failures of the main or auxiliary compressor $-5.5 \%$,

2.2. failures of pneumatic conduits $-2.4 \%$,

2.3. failures of pneumatic valves (inter alia, main or auxiliary valve of the driver, reducing, end, safety valve) $-3.4 \%$,

2.4. failures of brake elements (e.g. levers, couplers, coupling pins, bushings, couplings, brake blocks) $-1.2 \%$,

2.5. failures of the actuator in the brake system $-0.4 \%$,

2.6. failures of other elements in the pneumatic circuit $-0.6 \%$, 
2.7. failures of other elements in the pneumatic conduit $-2.0 \%$,

3. Vehicle drive safety control devices:

3.1. failures of ABP (SHP, CA, RS), metering device (speed meter, ammeter) or radiotelephone $-10.4 \%$.

A total of 151 failures, qualified as hazardous ones, were recorded in the analysed period of operation. The proportion of hazardous failures in the total number of failures was $30.6 \%$. Presented below are selected indicators relating to the safety of a $6 \mathrm{Dg}$ locomotive which are defined in chapter 3 .

\section{a) Distribution function of the Time to Failure FH(t) and Mean Time to Hazardous Failure MTTHF}

Table 1 presents the parameters of the Weibull distribution of the Time to Failure and the Mean time to Hazardous Failure (MTTHF) for assemblies and subassemblies influencing railway safety. The analysis used the capacities of the MiniTab reliability analysis. In order to verify the hypotheses on the distribution form, a confidence level of $95 \%$ was adopted and the Anderson-Darling (A-D) test proposed on the software was applied. The maximum likelihood and the least squares method was applied to estimate the parameters of the distribution of the times to failure [18].

Table 1

Parameters of the Time to Failure of assemblies and subassemblies influencing railway safety of a $6 \mathrm{Dg}$ locomotive

\begin{tabular}{|c|c|c|c|c|}
\hline \multirow[t]{2}{*}{ No. } & \multirow[t]{2}{*}{ Description (failure code) } & \multicolumn{2}{|c|}{$\begin{array}{l}\text { Weibull distribution } \\
\text { parameters }(\mathbf{a}, \mathbf{b})\end{array}$} & \multirow{2}{*}{$\begin{array}{c}\text { MTTHF } \\
\text { [hr] }\end{array}$} \\
\hline & & $\mathbf{a}$ & b & \\
\hline 1. & Running gear & & & \\
\hline 1.1 & $\begin{array}{l}\text { failures and wear of the wheels' outer contour } \\
(605)\end{array}$ & 1.5193 & 6336.1 & 5711.2 \\
\hline 2. & $\begin{array}{l}\text { Brake system (pneumatic and mechanical } \\
\text { parts) }\end{array}$ & & & \\
\hline 2.1 & failures of the main or auxiliary compressor (565) & 1.5434 & 5655.2 & 5088.5 \\
\hline 2.2 & $\begin{array}{l}\text { failures of the engine driving the main or auxiliary } \\
\text { compressor of rail vehicle ( } 570)\end{array}$ & 1.2142 & 41034.1 & 38483.2 \\
\hline
\end{tabular}


cd. tabeli 1

\begin{tabular}{||c|l|c|c|c||}
\hline 2.3 & $\begin{array}{l}\text { failures of pneumatic valves (inter alia, main or } \\
\text { auxiliary valve of the driver, reducing, end, safety } \\
\text { valve) (575) }\end{array}$ & 1.7262 & 6010.36 & 5357.3 \\
\hline 2.4 & failures of pneumatic conduits (585) & 1.0096 & 22993.4 & 22901.9 \\
\hline 2.5 & failures of the actuator in the brake system (590) & 1.0221 & 115243.0 & 114214.0 \\
\hline 2.6 & $\begin{array}{l}\text { failures of other elements in the pneumatic circuit } \\
\text { (595) }\end{array}$ & 1.7743 & 5867.30 & 5221.5 \\
\hline 2.7 & $\begin{array}{l}\text { failures of elements of the brake, e.g. levers, } \\
\text { couplers, coupling pins, bushings, couplings, } \\
\text { brake blocks) (615) }\end{array}$ & 2.4482 & 8806.18 & 7809.6 \\
\hline 3. & Train drive safety control engineering devices & & 6897.3 \\
\hline 3.1 & $\begin{array}{l}\text { Failures of vehicle safety controls (SHP, CA, RS), } \\
\text { metering device (speed meter, ammeter) or } \\
\text { radiotelephone (625) }\end{array}$ & 1.0042 & 6909.63 & 6 \\
\hline
\end{tabular}

The analysis done at the level of the locomotive as a system demonstrated a correspondence between the empirical distribution of the time to hazardous failure and the two-parameter Weibull distribution with the following parameters: $a=1.4189, b=8345.73$. Based on the estimated parameters, the distribution function of the time to hazardous failure was determined:

$$
F_{H}(t)=1-\exp \left(-\frac{t}{b}\right)^{a}=1-\exp \left(-1.2 \cdot 10^{-4} t\right)^{1,4189}, \text { for } t \geq 0
$$

and the time to hazardous failure of the locomotive:

$$
\begin{aligned}
& \text { MTTHF }=\int_{0}^{\infty} t \cdot f_{H}(t) d t=\int_{0}^{\infty} t \cdot \frac{a}{b}\left(\frac{t}{b}\right)^{a-1} \exp \left(-\frac{t}{b}\right)^{a} d t=\Gamma\left(1+\frac{1}{a}\right) \cdot b= \\
& =7,590.9[h r]
\end{aligned}
$$

\section{b) Mean Time Between Hazardous Failures $M T B H F$ and Mean Distance Between Hazardous Failures, $M D B H F$}

Table 2 presents the mean times between hazardous failures for selected gears and elements of a $6 \mathrm{Dg}$ locomotive which influence railway safety. 
Table 2

Mean time and distance between failures for selected gears and elements of a 6Dg locomotive

\begin{tabular}{|c|c|c|c|c|}
\hline No. & Description & $\begin{array}{l}\text { Number } \\
\text { of } \\
\text { failures }\end{array}$ & $\begin{array}{c}\text { МТВHF } \\
{[\mathrm{hr}]}\end{array}$ & $\begin{array}{c}\text { MDBHF } \\
{[\mathbf{k m}]}\end{array}$ \\
\hline 1. & Running gear & 18 & 27506.3 & 178200.0 \\
\hline 1.1 & failures and wear of the wheel's outer contour & 18 & 27506.3 & 178200.0 \\
\hline 2. & Brake system (pneumatic and mechanical parts) & 77 & 6430.0 & 41657.1 \\
\hline 2.1 & Failures of the main or auxiliary compressor & 27 & 18337.5 & 118800.0 \\
\hline 2.2 & $\begin{array}{l}\text { failures of the engine driving the main or auxiliary } \\
\text { compressor of rail vehicle }\end{array}$ & 3 & 165037.5 & 1069200.0 \\
\hline 2.3 & $\begin{array}{l}\text { failures of pneumatic valves (inter alia, main or } \\
\text { auxiliary valve of the driver, reducing, end, safety } \\
\text { valve) }\end{array}$ & 17 & 29124.3 & 188682.4 \\
\hline 2.4 & failures of pneumatic conduits & 12 & 41259.4 & 267300.0 \\
\hline 2.5 & failures of the actuator in the brake system & 2 & 247556.3 & 1603800.0 \\
\hline 2.6 & failures of other elements in the pneumatic circuit & 10 & 49511.3 & 320760.0 \\
\hline 2.7 & $\begin{array}{l}\text { Failures of elements of the brake, e.g. levers, } \\
\text { couplers, coupling pins, bushings, couplings, brake } \\
\text { blocks }\end{array}$ & 6 & 82518.8 & 534600.0 \\
\hline 3. & Vehicle drive safety control devices & 56 & 8841.3 & 57278.6 \\
\hline 3.1 & $\begin{array}{l}\text { failures of vigilance devices (e.g. SHP/KHP, CA, } \\
\text { RS), metering device (speed meter, ammeter) or } \\
\text { radiotelephone }\end{array}$ & 56 & 8841.3 & 57278.6 \\
\hline
\end{tabular}

Based on the figures calculated above, the $M T B H F$ and the $M D B H F$ were calculated at the locomotive level:

$$
\begin{gathered}
M T B H F=\frac{1}{\sum_{i=1}^{n}\left(\frac{1}{M T B H F_{i}}\right)}=3,278.9[\mathrm{hr}] \\
M D B H F=\frac{1}{\sum_{i=1}^{n}\left(\frac{1}{M D B H F_{i}}\right)}=21,242.4[\mathrm{~km}]
\end{gathered}
$$




\section{c) Frequency of hazardous failures $\boldsymbol{H}$ for locomotive assemblies and subassemblies}

Table 3 presents the frequency of failures which are hazardous to subassemblies of a $6 \mathrm{Dg}$ locomotive influencing railway safety. In a comparison of the figures generated for locomotives of a similar type used by other railway carriers, in an average daily time of operation of a locomotive of 16.3 [hrs/day], the frequencies of occurrence of hazards are above the average and are considered to be acceptable.

Table 3

Frequency of occurrence of hazards to systems relevant for railway safety

\begin{tabular}{|c|l|c|c|c||}
\hline No. & \multicolumn{1}{|c|}{ Description } & $\begin{array}{c}\text { Percentage } \\
\text { of total } \\
\text { failures }\end{array}$ & $\begin{array}{c}\text { Hazard } \\
\text { frequency } \\
\text { [damage/hr] }\end{array}$ & $\begin{array}{c}\text { Hazard } \\
\text { frequency } \\
\text { [damage/ km] }\end{array}$ \\
\hline 1 & \multicolumn{1}{|c|}{ Hazardous failures in total } & $\mathbf{3 0 , 6 0 \%}$ & $\mathbf{3 , 0 5} \cdot \mathbf{1 0}^{-4}$ & $\mathbf{4 , 7 1 \cdot 1 0 ^ { - 5 }}$ \\
\hline 2 & $\begin{array}{l}\text { Failure and wear of wheel's outer } \\
\text { contour }\end{array}$ & $3.64 \%$ & $3.64 \cdot 10^{-5}$ & $5.61 \cdot 10^{-6}$ \\
\hline 3 & $\begin{array}{l}\text { Failure of main or auxiliary } \\
\text { compressor }\end{array}$ & $5.47 \%$ & $5.45 \cdot 10^{-5}$ & $8.42 \cdot 10^{-6}$ \\
\hline 4 & $\begin{array}{l}\text { Failures of the engine driving the main } \\
\text { or auxiliary compressor of rail vehicle }\end{array}$ & $0.61 \%$ & $6.06 \cdot 10^{-6}$ & $9.35 \cdot 10^{-7}$ \\
\hline 5 & Failures of pneumatic valves & $3.44 \%$ & $3.43 \cdot 10^{-5}$ & $5.30 \cdot 10^{-6}$ \\
\hline 6 & Failures of pneumatic conduits & $2.43 \%$ & $2.42 \cdot 10^{-5}$ & $3.74 \cdot 10^{-6}$ \\
\hline 7 & $\begin{array}{l}\text { Failures of the actuator in the brake } \\
\text { system }\end{array}$ & $0.40 \%$ & $4.04 \cdot 10^{-6}$ & $6.24 \cdot 10^{-7}$ \\
\hline 8 & $\begin{array}{l}\text { Failures of other elements in the } \\
\text { pneumatic conduit }\end{array}$ & $2.02 \%$ & $2.02 \cdot 10^{-5}$ & $3.12 \cdot 10^{-6}$ \\
\hline 9 & Failures of elements of the brake & $1.21 \%$ & $1.21 \cdot 10^{-5}$ & $1.87 \cdot 10^{-6}$ \\
\hline 10 & $\begin{array}{l}\text { Failures of the safety controls, } \\
\text { metering device or radiotelephone }\end{array}$ & $11.34 \%$ & $1.13 \cdot 10^{-4}$ & $1.75 \cdot 10^{-5}$ \\
\hline 11 & Corrosion wear of the support & $0.01 \%$ & $9.98 \cdot 10^{-8}$ & $1.54 \cdot 10^{-8}$ \\
\hline 12 & Cracks in the support's nodes & $0.01 \%$ & $9.98 \cdot 10^{-8}$ & $1.54 \cdot 10^{-8}$ \\
\hline 13 & Cracks in the bogie's frame nodes & $0.01 \%$ & $9.98 \cdot 10^{-8}$ & $1.54 \cdot 10^{-8}$ \\
\hline
\end{tabular}




\section{Conclusions}

One of the most important stages of the methodology of building the strategy of maintenance of rail vehicles is to conduct the RAMS analysis in the area of safety which comprises: analysis of failures, identification of assemblies and subassemblies relevant from the viewpoint of railway safety and determination of durability and reliability characteristics. Using the selected example and based on the reliability data gathered during the 15 months of operation of $756 \mathrm{Dg}$ locomotives, selected safety ratios were determined for the locomotive subassemblies whose damage causes a hazard to the reliability and railway safety.

The RAMS analysis enables a proper classification of hazards, quantification of the frequency of their occurrence, as well as the adoption of the appropriate criteria for risk assessment which is another stage in the methodology of building the strategy of maintenance of rail vehicles.

\section{References}

1. Analiza kosztu cyklu istnienia (LCC) lokomotywy spalinowej serii ST48 typu 15D/A. Praca nr M-8/494/2015/P, Politechnika Krakowska, July 2015.

2. Directive 2004/49/EC of the European Parliament and of the Council of 29 April 2004 on safety on the Community railways.

3. Directive 2008/57/EC of the European Parliament and of the Council of 17 June 2008 on the interoperability of the rail system within the Community (OJ EU L 191, 18.7.2008).

4. Flammini F.: Railway Safety, Reliability, and Security: Technologies and Systems Engineering, IGI Global, 2012.

5. Manzini R., Regattieri A., Pham H., Ferrari E.: Maintenance for Industrial Systems. Springer, 2010.

6. Młynarski S., Pilch R., Smolnik M., Kaczor G., Szkoda M., Szybka J.: Effect of Selected Factors on The Safety Integrity Level (SIL). Journal of KONBiN, vol. 35 (3), 2015.

7. O’Connor P.: Practical Reliability Engineering, 4th edition, John Wiley \& Sons, 2010.

8. Optymalizacja planu utrzymania lokomotyw spalinowych serii SM42 eksploatowanych przez CTL Logistics Sp. z o.o. Praca nr M-8/160/2016/P, Politechnika Krakowska, Kraków, May 2016.

9. Optymalizacja planu utrzymania wagonów cystern typu 440Ra eksploatowanych przez CTL Logistics Sp. z o.o. Praca nr M-8/220/2016/P, Politechnika Krakowska, Kraków, May 2016. 
10. Optymalizacja planu utrzymania wagonów samowyładowczych typu 418V własności CTL Maczki-Bór S.A. Praca nr M-8/543/2017/P, Politechnika Krakowska, Kraków, June 2017.

11. PN-EN 50126-1:2018-02 Zastosowania kolejowe - Specyfikowanie i wykazywanie niezawodności, dostępności, podatności utrzymaniowej i bezpieczeństwa (RAMS) Część 1: Proces ogólny RAMS.

12. PN-EN 50129:2007 Zastosowania kolejowe - Systemy łączności, przetwarzania danych i sterowania ruchem - Elektroniczne systemy sterowania ruchem związane $\mathrm{z}$ bezpieczeństwem.

13. PN-EN 61508 (seria) Bezpieczeństwo funkcjonalne elektrycznych /elektronicznych/ programowalnych elektronicznych systemów związanych z bezpieczeństwem.

14. Commission Implementing Regulation (EU) No 402/2013 of 30 April 2013 on the common safety method for risk evaluation and assessment and repealing Regulation (EC) No 352/2009 (OJ EU L121 of 03.05.2013).

15. Smith D. J.: Reliability, Maintainability and Risk: Practical Methods for Engineers, 8th edition. Butterworth-Heinemann, 2011.

16. Stapelberg R. F.: Handbook of reliability, availability, maintainability and safety in engineering design. Springer Science \& Business Media, 2009.

17. Szkoda M., Kaczor G.: RAMS analysis of railway vehicles' lifecycle. Journal of KONBiN, vol. 41, 2017.

18. Szkoda M.: Kształtowanie potencjału przewozowego przedsiębiorstw transportu kolejowego. Monografia. Wydawnictwo Politechniki Krakowskiej, Kraków 2017, ISBN: 978-83-7242-925-4.

19. Szkoda M., Satora M.: Change in the maintenance strategy as a method of improving the efficiency of the process of operation of railway means of transport. MATEC Web of Conferences, 234/2018.

20. Szopa T.: Niezawodność i bezpieczeństwo. Oficyna Wydawnicza Politechniki Warszawskiej, Warszawa 2009. 


\section{METODYKA BUDOWY STRATEGII UTRZYMANIA KOLEJOWYCH ŚRODKÓW TRANSPORTU Z WYKORZYSTANIEM ANALIZY RAMS W OBSZARZE BEZPIECZEŃSTWA}

\section{Wstęp}

Przeprowadzone w Instytucie Pojazdów Szynowych Politechniki Krakowskiej prace badawczo-rozwojowe odnośnie budowy strategii utrzymania [1, 8-10] dowodza, że koszty utrzymania stanowią do 36,4\% kosztów cyklu istnienia (ang. Life Cycle Costs - LCC) kolejowych środków transportu i są drugą po kosztach zużycia energii lub paliwa dominującą kategorią kosztów. W 25-letnim okresie eksploatacji koszty te mogą sięgać od 2,1 mln dla lokomotyw manewrowych do 13,8 mln zł dla elektrycznych zespołów trakcyjnych. W ostatnich latach przedsięwzięcia związane ze zmianą dotychczas stosowanych strategii utrzymania środków transportu (lokomotyw elektrycznych i spalinowych, wagonów towarowych, pasażerskich oraz pojazdów specjalnych) są bardzo często podejmowane przez przedsiębiorstwa transportu kolejowego. Prowadzone działania nakierunkowane są przede wszystkim na oszczędności w kosztach utrzymania, lecz często dokonywane są z pominięciem oceny ryzyka zagrożeń i wpływu proponowanych zmian na bezpieczeństwo systemu kolejowego. Różnego rodzaju zmiany w obszarze utrzymania mogą przyczynić się do pogorszenia stanu technicznego pojazdów i stanowić potencjalne źródło zagrożeń dla systemu kolejowego.

\section{Metodyka budowy strategii utrzymania kolejowych środków transportu}

W odpowiedzi na duże zapotrzebowanie przedsiębiorstw kolejowych, na podstawie analizy specjalistycznej literatury oraz doświadczenia zdobytego z realizacji prac badawczo-naukowych, podjęto próbę opracowania metodyki budowy i rozwoju strategii utrzymania kolejowych środków transportu, uwzględniającej efektywność proponowanych rozwiązań oraz ich wpływ na bezpieczeństwo systemu kolejowego [810]. Procedurę postępowania w stworzonej metodyce przedstawiono na rys. 1. 


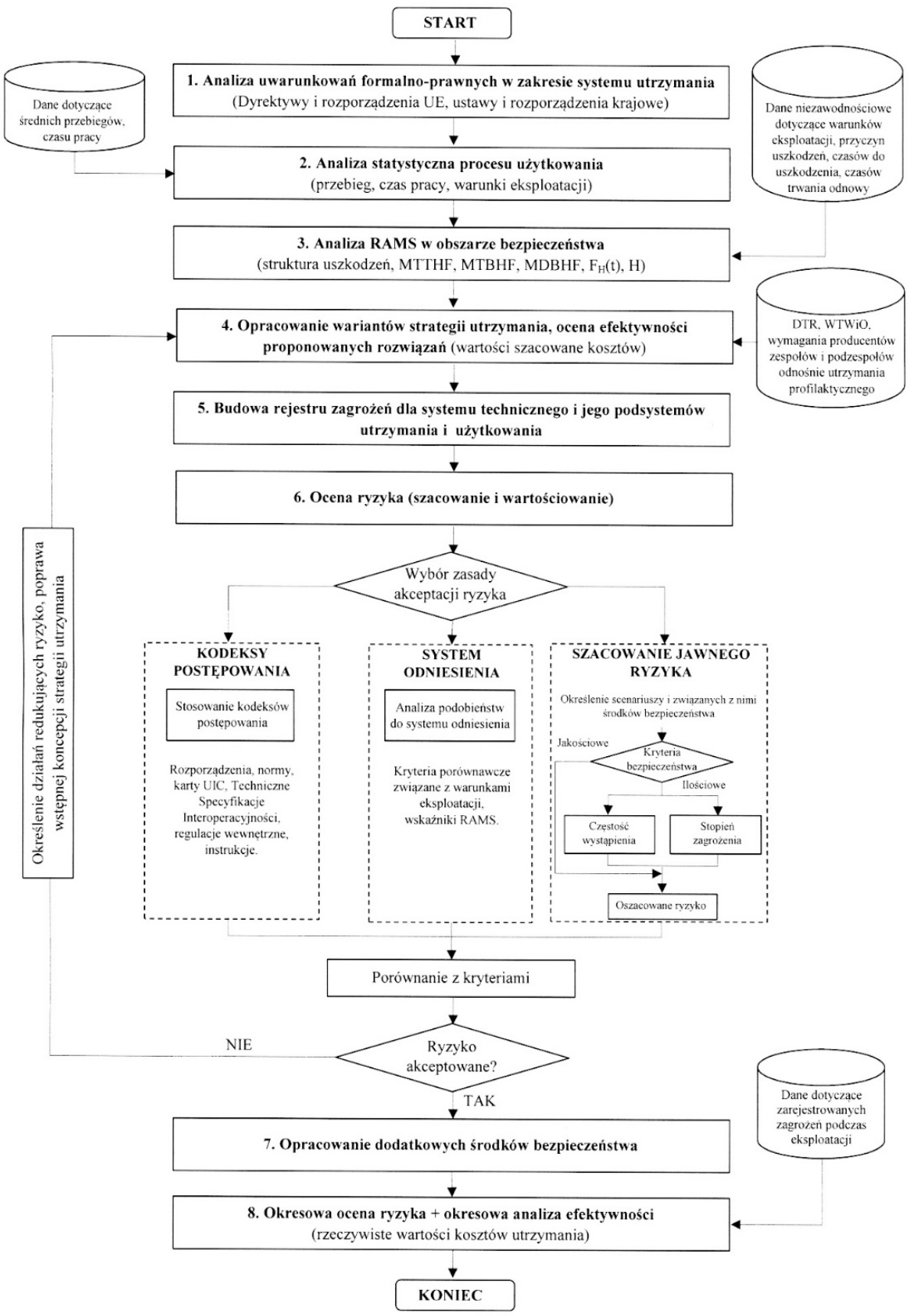

Rys. 1. Algorytm budowy (opracowania nowej lub zmiany istniejącej) strategii utrzymania kolejowych środków transportu 
Jednym $\mathrm{z}$ najistotniejszych etapów $\mathrm{w}$ opracowanej metodyce jest analiza niezawodnościowa RAMS w obszarze bezpieczeństwa, której podstawy teoretyczne opisano w normie PN-EN 50126:2018 Zastosowania kolejowe - Specyfikacja niezawodności, dostępności, podatności utrzymaniowej i bezpieczeństwa $[11,18,19]$. Bezpieczeństwo oznacza brak niedopuszczalnego ryzyka, które opisuje częstotliwość wypadków i incydentów prowadzących do szkody (spowodowanej zagrożeniem) oraz stopień powagi tej szkody [14]. Wg definicji przedstawionej w normie PN-EN 50126 bezpieczeństwo oznacza brak katastrofalnych skutków dla użytkownika i środowiska.

\section{Charakterystyki wykorzystywane $w$ analizie niezawodnościowej RAMS w obszarze bezpieczeństwa}

Ocena bezpieczeństwa w transporcie kolejowym jest tematem bardzo złożonym. Nadrzędnym dokumentem formalnym w ocenie bezpieczeństwa w transporcie kolejowym jest Dyrektywa 2004/49/WE Parlamentu Europejskiego i Rady z dnia 29 kwietnia 2004 r. w sprawie bezpieczeństwa kolei wspólnotowych. Aktualnie obowiązująca wersja została zmieniona Dyrektywą Parlamentu Europejskiego i Rady 2008/1 10/WE z dnia 16 grudnia 2008 r., Dyrektywą Komisji 2014/88/UE z dnia 9 lipca 2014 roku oraz Dyrektywą Parlamentu Europejskiego i Rady 2016/798 z dnia 11 maja 2016 roku. Od wejścia w życie postanowień Dyrektywy kwestie związane $\mathrm{z}$ bezpieczeństwem zostały zinstytucjonalizowane na poziomie Unii Europejskiej poprzez wprowadzenie wspólnych celów, wymagan i wskaźników bezpieczeństwa w powiązaniu z wymaganiami zawartymi w Technicznych Specyfikacjach Interoperacyjności [3]. Wspólne wskaźniki bezpieczeństwa (CSI) dotyczą danych statystycznych odnoszących się do wypadków w transporcie kolejowym, skutków wypadków, bezpieczeństwa technicznego infrastruktury kolejowej i zarządzania bezpieczeństwem. Ogólny poziom bezpieczeństwa w transporcie kolejowym, charakteryzowany jest poprzez dwa mierniki:

- miernik wypadków, zdefiniowany jako liczba znaczących wypadków w stosunku do pracy eksploatacyjnej [liczba wypadków/mln pockm],

- miernik ciężkości wypadków, zdefiniowany jako liczba ofiar znaczących wypadków wyrażonej w FWSI (umowna miara liczby ofiar wypadków, w której zabici uwzględniani są $\mathrm{z}$ wagą 1 , a ciężko ranni $\mathrm{z}$ wagą 0,1 ) w stosunku do pracy eksploatacyjnej [FWSI/mln pockm] [2].

W przepisach krajowych zostały one określone w Rozporządzeniu Ministra Infrastruktury i Rozwoju z dnia 21 lipca 2015 r. w sprawie wspólnych wskaźników bezpieczeństwa. Rozporządzenie określa wskaźniki, które Prezes Urzędu Transportu 
Kolejowego zamieszcza w rocznym raporcie w sprawie bezpieczeństwa, na podstawie sprawozdań otrzymywanych od zarządców i przewoźników kolejowych. Wskaźniki te odnoszą się do:

- działalności podstawowej transportu kolejowego,

- zdarzeń kolejowych i ich skutków,

- samobójstw,

- towarów niebezpiecznych,

- zdarzeń poprzedzających wypadki,

- ekonomicznych skutków wypadków otrzymywane od zarządców infrastruktury i przewoźników kolejowych,

- bezpieczeństwa technicznego infrastruktury kolejowej.

Lista wskaźników zamieszczona w załączniku do Dyrektywy 2004/49/WE jest obligatoryjna, jednak nie stanowi wykazu wyczerpującego.

W ocenie bezpieczeństwa kolejowych środków transportu niezbędne jest zdefiniowanie wskaźników odnoszących się do dwóch obszarów: zawodności oraz zagrożenia - stanu, który może prowadzić do powstania strat. W tym celu pomocne mogą być wskaźniki zdefiniowane w podpunktach a $\div \mathrm{d}$, w oparciu o normy z dziedziny bezpieczeństwa: PN-EN 61508, PN-EN 50129, PN-EN 50126 [11-13] oraz specjalistyczną literaturę dotyczącą oceny nieuszkadzalności, gotowości, podatności na utrzymanie i bezpieczeństwa $[4,5,7,15,16]$, odnoszące się do prawdopodobieństwa wystapienia zdarzeń niepożądanych, a w szczególności tzw. uszkodzeń niebezpiecznych oraz skutków tych zdarzeń.

\section{a) Prawdopodobieństwo wystąpienia zdarzenia niepożądanego $F_{H}(t)$}

$F_{H}(t)$ jest to prawdopodobieństwo, że uszkodzenie pojazdu nastapi nie później niż w chwili $t$ i wyrażone jest funkcją gęstości prawdopodobieństwa czasu pracy do zdarzenia niepożądanego $f_{H}(t)$ :

$$
F_{H}(t)=\int_{0}^{t} f_{H}(x) d x t \geq 0
$$

b) Oczekiwany czas pracy do zdarzenia niepożądanego $M T T H F$

$$
\text { MTTHF }=\int_{0}^{\infty} t \cdot f_{H}(t) d t
$$

oznaczenia $-\mathrm{jw}$. 


\section{c) Oczekiwany czas pracy między zdarzeniami niepożądanymi}

MTBHF

$$
M T B H F=\int_{0}^{\infty} t \cdot f_{B H}(t) d t(3)
$$

gdzie:

$f_{B H}(t)$ - funkcja gęstości prawdopodobieństwa czasu pracy między $(k-1)$ odnową, a zdarzeniem niepożądanym o numerze $k$

Oszacowanie empiryczne:

$$
M T B H F^{*}=\frac{1}{N(0)}\left(t_{H 1}^{(k)}+t_{H 2}^{(k)}+\cdots+t_{H N(0)}^{(k)}=\frac{1}{N(0)} \sum_{i=1}^{N(0)} t_{H i}^{(k)}\right.
$$

gdzie:

$N(0)$ - liczba badanych pojazdów,

$t_{H i}^{(k)}$ - realizacja losowa czasu pracy pojazdu po $(k-1)$ odnowie do chwili zdarzenia niepożądanego o numerze $k$.

Jeżeli $\mathrm{w}$ powyższym wzorze zamiast czasu zostanie uwzględniony łączny przebieg $\mathrm{w}$ przedziale czasu $(0, t)$, to otrzyma się średni przebieg między zdarzeniami niepożądanymi $M D B H F$ wyrażony w kilometrach przebiegu.

\section{d) Częstość wystąpienia zdarzenia niepożądanego $H$}

$$
H=\frac{n_{H}(t)}{T}
$$

gdzie:

$n_{H}(t)$ - liczba zdarzeń niepożądanych w przedziale czasu $(0, t)$,

$T \quad$ - łączny czas pracy pojazdu w przedziale czasu $(0, t)$.

Powyższy wskaźnik jest podobny do wskaźnika PFH (ang. Probability of Failure per Hour) prawdopodobieństwa uszkodzenia na godzinę, używanego do oceny poziomu nienaruszalności bezpieczeństwa SIL (Safety Integrity Level) dla elektronicznych urządzeń i systemów sterowania ruchem kolejowym $[6,13,17]$. 


\section{Przykład aplikacji wybranych aspektów analizy niezawodnościowej RAMS w obszarze bezpieczeństwa}

W niniejszym rozdziale przedstawiono wybrane aspekty zastosowania analizy niezawodnościowej RAMS w budowie strategii utrzymania kolejowych środków transportu na przykładzie lokomotywy spalinowej typu 6Dg. Analiza RAMS w obszarze bezpieczeństwa obejmowała następujące etapy: analizę uszkodzeń, identyfikację zespołów, podzespołów i elementów lokomotywy istotnych z punktu widzenia bezpieczeństwa ruchu kolejowego oraz wyznaczenie charakterystyk trwałościowo-niezawodnościowych stanowiących podstawę do oceny i wyceny ryzyka.

\subsection{Badania eksploatacyjne}

Analiza RAMS w obszarze bezpieczeństwa w omawianym przykładzie opierała się na wynikach badań eksploatacyjnych wybranej próby 75 lokomotyw typu 6Dg używanych przez przewoźnika kolejowego w okresie 15 miesięcy. Umożliwiło to obserwację przebiegu eksploatacji lokomotyw w różnorodnych warunkach, a tym samym pozyskanie wiarygodnych danych do analizy niezawodnościowej. Dane niezawodnościowe gromadzone były w systemie informatycznym przewoźnika umożliwiającym precyzyjne rejestrowanie czasów poprawnej pracy (ang. Time to Failure - TTF) i czasów odnów (ang. Time to Restore - TTR).

\subsection{Struktura uszkodzeń lokomotyw typu 6Dg}

W analizowanym okresie eksploatacji zarejestrowano łącznie 494 uszkodzeń, czyli średnio 6,6 [uszk./lokomotywe]. Na podstawie przeprowadzonej analizy stwierdzono, że do najczęściej występujących uszkodzeń lokomotywy zarejestrowanych podczas eksploatacji należą:

- uszkodzenia elementów, aparatów i urządzeń obwodów elektrycznych $23,7 \%$,

- uszkodzenia silnika spalinowego - $16,8 \%$,

- uszkodzenia urządzeń czujności - 11,3\%,

- uszkodzenia wywołane niewłaściwą obsługą pojazdu-9,1\%,

- uszkodzenia baterii akumulatorów - 7,9\%.

Dane statystyczne potwierdziły podkreślaną w literaturze prawidłowość, że jednym z najbardziej zawodnych elementów systemu jest człowiek (operator), 
który przez swoje błędy powoduje powstawanie zagrożeń dla siebie i otoczenia [20]. Uszkodzenia wywołane niewłaściwą obsługą lokomotywy stanowią 9,1\% uszkodzeń ogółem.

\subsection{Wskaźniki RAMS związane z bezpieczeństwem}

Z punktu widzenia oceny bezpieczeństwa opracowywanej strategii utrzymania lokomotywy $6 \mathrm{Dg}$, najważniejsze były wskaźniki związane z elementami istotnymi, czyli zespołami i podzespołami lokomotywy, których uszkodzenia powodują zagrożenia dla niezawodności oraz bezpieczeństwa ruchu kolejowego (tzw. uszkodzenia niebezpieczne). Analiza zgromadzonych danych statystycznych o przyczynach oraz rodzajach zdarzeń niepożądanych lokomotywy 6Dg wykazała, że do najbardziej istotnych uszkodzeń ze względu na ryzyko należą:

1. Układ biegowy:

1.1. uszkodzenia i zużycia zarysu zewnętrznego kół - 3,6\%,

2. Układ pneumatyczny i hamulcowy:

2.1. uszkodzenia sprężarki głównej lub pomocniczej - 5,5\%,

2.2. uszkodzenia przewodów pneumatycznych $-2,4 \%$,

2.3.uszkodzenia zaworów pneumatycznych (m.in. głównego lub pomocniczego zaworu maszynisty, zaworu redukcyjnego, końcowego, bezpieczeństwa) $-3,4 \%$,

2.4. uszkodzenia elementów hamulca (np. dźwignie, ciagła, sworznia, tuleje, złączki, klocki hamulcowe) - 1,2\%,

2.5. uszkodzenia siłownika w układzie hamulcowym $-0,4 \%$,

2.6. uszkodzenia silnika napędzającego sprężarkę główną lub pomocniczą pojazdu trakcyjnego $-0,6 \%$,

2.7. uszkodzenia pozostałych elementów $\mathrm{w}$ obwodzie pneumatycznym $2,0 \%$,

3. Urządzenia automatyki bezpieczeństwa ruchu pojazdu:

3.1. uszkodzenia ABP (SHP, CA, RS), przyrządu pomiarowego (prędkościomierz, amperomierz) lub radiotelefonu - 10,4\%.

W analizowanym okresie eksploatacji zarejestrowano łącznie 151 uszkodzeń, które zakwalifikowano jako uszkodzenia niebezpieczne. Udział uszkodzeń niebezpiecznych w uszkodzeniach ogółem wyniósł 30,6\%. Poniżej przedstawiono wybrane wskaźniki związane z bezpieczeństwem lokomotywy typu 6Dg, które zdefiniowano w rozdziale 3. 


\section{a) Dystrybuanta czasu poprawnej pracy $F_{H}(t)$ i średni czas pracy do uszkodzenia niebezpiecznego $M T T H F$}

W tabeli 1 zestawiono parametry rozkładu Weibulla czasu poprawnej pracy oraz średni czas pracy do uszkodzenia niebezpiecznego MTTHF dla zespołów i podzespołów mających wpływ na bezpieczeństwo ruchu kolejowego. W analizie wykorzystano możliwości pakietu analizy niezawodnościowej MiniTab. Do weryfikacji hipotez o postaci rozkładu przyjęto poziom ufności $95 \%$ oraz zastosowano proponowany w oprogramowaniu test Andersona-Darlinga (A-D). Do estymacji parametrów rozkładu czasów poprawnej pracy wykorzystana została metoda największej wiarygodności oraz najmniejszych kwadratów [18].

Tabela 1

Parametry rozkładu czasu poprawnej pracy zespołów i podzespołów mających wpływ na bezpieczeństwo ruchu kolejowego lokomotywy typu 6Dg

\begin{tabular}{|c|c|c|c|c|}
\hline \multirow[t]{2}{*}{ Lp. } & \multirow{2}{*}{ Wyszczególnienie (kod uszkodzenia) } & \multicolumn{2}{|c|}{$\begin{array}{l}\text { Parametry rozkladu } \\
\text { Weibulla }(\mathbf{a}, \mathbf{b})\end{array}$} & \multirow{2}{*}{$\begin{array}{l}\text { MTTHF } \\
\text { [godz.] }\end{array}$} \\
\hline & & $\mathbf{a}$ & b & \\
\hline 1. & Układ biegowy & & & \\
\hline 1.1 & uszkodzenia i zużycia zarysu zewnętrznego kół (605) & 1,5193 & 6336,1 & 5711,2 \\
\hline 2. & Układ pneumatyczny i hamulcowy & & & \\
\hline 2.1 & uszkodzenia sprężarki głównej lub pomocniczej (565) & 1,5434 & 5655,2 & 5088,5 \\
\hline 2.2 & $\begin{array}{l}\text { uszkodzenia silnika napędzającego sprężarkę główną } \\
\text { lub pomocniczą pojazdu trakcyjnego (570) }\end{array}$ & 1,2142 & 41034,1 & 38483,2 \\
\hline 2.3 & $\begin{array}{l}\text { uszkodzenia zaworów pneumatycznych (m.in. } \\
\text { głównego lub pomocniczego zaworu maszynisty, } \\
\text { zaworu redukcyjnego, końcowego, bezpieczeństwa) } \\
(575)\end{array}$ & 1,7262 & 6010,36 & 5357,3 \\
\hline 2.4 & uszkodzenia przewodów pneumatycznych (585) & 1,0096 & 22993,4 & 22901,9 \\
\hline 2.5 & uszkodzenia siłownika w układzie hamulcowym (590) & 1,0221 & 115243,0 & 114214,0 \\
\hline 2.6 & $\begin{array}{l}\text { uszkodzenia pozostałych elementów w obwodzie } \\
\text { pneumatycznym (595) }\end{array}$ & 1,7743 & 5867,30 & 5221,5 \\
\hline 2.7 & $\begin{array}{l}\text { uszkodzenia elementów hamulca np. dźwignie, ciagga, } \\
\text { sworznia, tuleje, złączki, klocki hamulcowe (615) }\end{array}$ & 2,4482 & 8806,18 & 7809,6 \\
\hline 3. & $\begin{array}{l}\text { Urządzenia automatyki bezpieczeństwa ruchu } \\
\text { pojazdu }\end{array}$ & & & \\
\hline 3.1 & $\begin{array}{l}\text { uszkodzenia urządzenia czujności (SHP, CA, RS), } \\
\text { przyrządu pomiarowego (prędkościomierz, } \\
\text { amperomierz) lub radiotelefonu (625) }\end{array}$ & 1,0042 & 6909,63 & 6897,3 \\
\hline
\end{tabular}


Przeprowadzona na poziomie lokomotywy jako systemu analiza wykazała zgodność empirycznego rozkładu czasu pracy do uszkodzenia niebezpiecznego $\mathrm{z}$ dwuparametrycznym rozkładem Weibulla o następujących parametrach: $a=1,4189$, $b=8345,73$. W oparciu o oszacowane parametry została wyznaczona dystrybuanta czasu pracy do uszkodzenia niebezpiecznego:

$$
F_{H}(t)=1-\exp \left(-\frac{t}{b}\right)^{a}=1-\exp \left(-1,2 \cdot 10^{-4} t\right)^{1,4189}, \text { dla } t \geq 0
$$

oraz oczekiwany czas pracy do uszkodzenia niebezpiecznego lokomotywy:

$$
\begin{aligned}
& \text { MTTHF }=\int_{0}^{\infty} t \cdot f_{H}(t) d t=\int_{0}^{\infty} t \cdot \frac{a}{b}\left(\frac{t}{b}\right)^{a-1} \exp \left(-\frac{t}{b}\right)^{a} d t=\Gamma\left(1+\frac{1}{a}\right) \cdot b= \\
& =7.590,9[\text { godz. }]
\end{aligned}
$$

\section{b) Średni czas pracy i przebieg między uszkodzeniami niebezpiecznymi, $M T B H F$ i $M D B H F$}

W tabeli 2 przedstawiono średnie czasy pracy i średnie przebiegi między uszkodzeniami niebezpiecznymi dla wybranych układów i elementów lokomotywy typu 6Dg, które mają wpływ na bezpieczeństwo ruchu kolejowego.

Tabela 2

Średni czas pracy i przebieg między uszkodzeniami niebezpiecznymi dla wybranych układów i elementów lokomotywy typu 6Dg

\begin{tabular}{|c|l|c|c|c||}
\hline \multicolumn{1}{|c|}{ Lp. } & \multicolumn{1}{|c|}{ Wyszczególnienie } & $\begin{array}{c}\text { Liczba } \\
\text { uszkodzeńn }\end{array}$ & $\begin{array}{c}\text { MTBHF } \\
{[\text { [godz.] }}\end{array}$ & $\begin{array}{c}\text { MDBHF } \\
{[\mathbf{k m}]}\end{array}$ \\
\hline $\mathbf{1 .}$ & Układ biegowy & $\mathbf{1 8}$ & $\mathbf{2 7 5 0 6 , 3}$ & $\mathbf{1 7 8 2 0 0 , 0}$ \\
\hline 1.1 & uszkodzenia i zużycia zarysu zewnętrznego kół & 18 & 27506,3 & 178200,0 \\
\hline $\mathbf{2 .}$ & Układ pneumatyczny i hamulcowy & $\mathbf{7 7}$ & $\mathbf{6 4 3 0 , 0}$ & $\mathbf{4 1 6 5 7 , \mathbf { 1 }}$ \\
\hline 2.1 & uszkodzenia sprężarki głównej lub pomocniczej & 27 & 18337,5 & 118800,0 \\
\hline 2.2 & $\begin{array}{l}\text { uszkodzenia silnika napędzającego sprężarkę główną } \\
\text { lub pomocniczą pojazdu trakcyjnego }\end{array}$ & 3 & 165037,5 & 1069200,0 \\
\hline 2.3 & $\begin{array}{l}\text { uszkodzenia zaworów pneumatycznych (m.in. } \\
\text { głównego lub pomocniczego zaworu maszynisty, } \\
\text { zaworu redukcyjnego, końcowego, bezpieczeństwa) }\end{array}$ & 17 & 29124,3 & 188682,4 \\
\hline
\end{tabular}


cd. tabeli 2

\begin{tabular}{|c|l|c|c|c||}
\hline \hline 2.4 & uszkodzenia przewodów pneumatycznych & 12 & 41259,4 & 267300,0 \\
\hline 2.5 & uszkodzenia siłownika w układzie hamulcowym & 2 & 247556,3 & 1603800,0 \\
\hline 2.6 & $\begin{array}{l}\text { uszkodzenia pozostałych elementów w obwodzie } \\
\text { pneumatycznym }\end{array}$ & 10 & 49511,3 & 320760,0 \\
\hline 2.7 & $\begin{array}{l}\text { uszkodzenia elementów hamulca np. dźwignie, ciagła, } \\
\text { sworznia, tuleje, złączki, klocki hamulcowe }\end{array}$ & 6 & 82518,8 & 534600,0 \\
\hline 3. & Urządzenia automatyki bezpieczeństwa pociągu & $\mathbf{5 6}$ & $\mathbf{8 8 4 1 , 3}$ & $\mathbf{5 7 2 7 8 , 6}$ \\
\hline & $\begin{array}{l}\text { uszkodzenia urządzenia czujności (np. SHP/KHP, CA, } \\
\text { RS), przyrządu pomiarowego (prędkościomierz, } \\
\text { amperomierz) lub radiotelefonu }\end{array}$ & 56 & 8841,3 & 57278,6 \\
\hline
\end{tabular}

Na podstawie obliczonych powyżej wartości, oszacowano średni czas $M T B H F$ i średni przebieg $M D B H F$ między uszkodzeniami niebezpiecznymi na poziomie lokomotywy:

$$
\begin{aligned}
& M T B H F=\frac{1}{\sum_{i=1}^{n}\left(\frac{1}{M T B H F_{i}}\right)}=3.278,9 \text { [godz. ] } \\
& M D B H F=\frac{1}{\sum_{i=1}^{n}\left(\frac{1}{M D B H F_{i}}\right)}=21.242,4[\mathrm{~km}]
\end{aligned}
$$

\section{c) Częstość uszkodzeń niebezpiecznych $H$ dla zespołów i podzespołów lokomotywy}

W tabeli 3 zestawiono częstość uszkodzeń niebezpiecznych dla zespołów oraz podzespołów lokomotywy 6Dg mających wpływ na bezpieczeństwo ruchu kolejowego. Dokonując porównania uzyskanych wartości do lokomotyw podobnego typu użytkowanych przez innych przewoźników kolejowych, przy uwzględnieniu średniego dobowego czasu pracy lokomotywy 16,3 [godz./dobę], obliczone częstości wystąpienia zagrożeń przyjmują wartości ponad średnią i uważane są za dopuszczalne. 
Tabela 3

Częstość wystąpienia zagrożenia ukladów istotnych dla bezpieczeństwa ruchu kolejowego

\begin{tabular}{|c|c|c|c|c|}
\hline Lp. & Wyszczególnienie & $\begin{array}{l}\text { Udział w } \\
\text { uszkodzeniach } \\
\text { ogółem }\end{array}$ & $\begin{array}{c}\text { Częstość } \\
\text { wystąpienia } \\
\text { zagrożenia } \\
\text { [uszk./ godz.] }\end{array}$ & $\begin{array}{c}\text { Częstość } \\
\text { wystąpienia } \\
\text { zagrożenia } \\
\text { [uszk./ km] }\end{array}$ \\
\hline 1 & Uszkodzenia niebezpieczne ogółem & $30,60 \%$ & $3,05 \cdot 10^{-4}$ & $4,71 \cdot 10^{-5}$ \\
\hline 2 & $\begin{array}{l}\text { Uszkodzenia i zużycia zarysu } \\
\text { zewnętrznego kół }\end{array}$ & $3,64 \%$ & $3,64 \cdot 10^{-5}$ & $5,61 \cdot 10^{-6}$ \\
\hline 3 & $\begin{array}{l}\text { Uszkodzenia sprężarki głównej lub } \\
\text { pomocniczej }\end{array}$ & $5,47 \%$ & $5,45 \cdot 10^{-5}$ & $8,42 \cdot 10^{-6}$ \\
\hline 4 & $\begin{array}{l}\text { Uszkodzenia silnika napędzającego } \\
\text { sprężarkę główną lub pomocniczą } \\
\text { pojazdu trakcyjnego }\end{array}$ & $0,61 \%$ & $6,06 \cdot 10^{-6}$ & $9,35 \cdot 10^{-7}$ \\
\hline 5 & $\begin{array}{l}\text { Uszkodzenia zaworów } \\
\text { pneumatycznych }\end{array}$ & $3,44 \%$ & $3,43 \cdot 10^{-5}$ & $5,30 \cdot 10^{-6}$ \\
\hline 6 & $\begin{array}{l}\text { Uszkodzenia przewodów } \\
\text { pneumatycznych }\end{array}$ & $2,43 \%$ & $2,42 \cdot 10^{-5}$ & $3,74 \cdot 10^{-6}$ \\
\hline 7 & $\begin{array}{l}\text { Uszkodzenia siłownika w układzie } \\
\text { hamulcowym }\end{array}$ & $0,40 \%$ & $4,04 \cdot 10^{-6}$ & $6,24 \cdot 10^{-7}$ \\
\hline 8 & $\begin{array}{l}\text { Uszkodzenia pozostałych elementów } \\
\text { w obwodzie pneumatycznym }\end{array}$ & $2,02 \%$ & $2,02 \cdot 10^{-5}$ & $3,12 \cdot 10^{-6}$ \\
\hline 9 & Uszkodzenia elementów hamulca & $1,21 \%$ & $1,21 \cdot 10^{-5}$ & $1,87 \cdot 10^{-6}$ \\
\hline 10 & $\begin{array}{l}\text { Uszkodzenia urządzenia czujności, } \\
\text { przyrządu pomiarowego lub } \\
\text { radiotelefonu }\end{array}$ & $11,34 \%$ & $1,13 \cdot 10^{-4}$ & $1,75 \cdot 10^{-5}$ \\
\hline 11 & Zużycie korozyjne ostoi & $0,01 \%$ & $9,98 \cdot 10^{-8}$ & $1,54 \cdot 10^{-8}$ \\
\hline 12 & Pęknięcia węzłów ostoi & $0,01 \%$ & $9,98 \cdot 10^{-8}$ & $1,54 \cdot 10^{-8}$ \\
\hline 13 & Pęknięcia węzłów ramy wózka & $0,01 \%$ & $9,98 \cdot 10^{-8}$ & $1,54 \cdot 10^{-8}$ \\
\hline
\end{tabular}




\section{Podsumowanie}

W opracowanej metodyce budowy strategii utrzymania kolejowych środków transportu jednym $\mathrm{z}$ najistotniejszych etapów jest przeprowadzenie analizy niezawodnościowej RAMS w obszarze bezpieczeństwa, która obejmuje: analizę uszkodzeń, identyfikację zespołów i podzespołów pojazdu istotnych z punktu widzenia bezpieczeństwa ruchu kolejowego oraz wyznaczenie charakterystyk trwałościowoniezawodnościowych. Na wybranym przykładzie, bazując na danych niezawodnościowych zgromadzonych podczas 15 -miesięcznej eksploatacji 75 lokomotyw typu 6Dg, wyznaczono wybrane wskaźniki związane z bezpieczeństwem dla podzespołów lokomotywy, których uszkodzenia powodują zagrożenia dla niezawodności oraz bezpieczeństwa ruchu kolejowego.

Na podstawie analizy RAMS możliwa jest właściwa klasyfikacja zagrożeń, kwantyfikacja częstości wystąpienia zagrożeń, a także przyjęcie właściwych kryteriów oceny ryzyka, co stanowi kolejny etap w opracowanej metodyce budowy strategii utrzymania kolejowych środków transportu.

\section{Literatura}

1. Analiza kosztu cyklu istnienia (LCC) lokomotywy spalinowej serii ST48 typu 15D/A. Praca nr M-8/494/2015/P, Politechnika Krakowska, lipiec 2015.

2. Dyrektywa 2004/49/WE Parlamentu Europejskiego i Rady z dnia 29 kwietnia 2004 r. w sprawie bezpieczeństwa kolei wspólnotowych.

3. Dyrektywa Parlamentu Europejskiego i Rady 2008/57/WE z dnia 17 czerwca 2008 r. w sprawie interoperacyjności systemu kolei we Wspólnocie (Dz.U. UE L 191, 18.7.2008).

4. Flammini F.: Railway Safety, Reliability, and Security: Technologies and Systems Engineering. IGI Global, 2012.

5. Manzini R., Regattieri A., Pham H., Ferrari E.: Maintenance for Industrial Systems. Springer, 2010.

6. Młynarski S., Pilch R., Smolnik M., Kaczor G., Szkoda M., Szybka J.: Effect of Selected Factors on The Safety Integrity Level (SIL). Journal of KONBiN, vol. 35 (3), 2015.

7. O'Connor P.: Practical Reliability Engineering, 4th edition. John Wiley \& Sons, 2010.

8. Optymalizacja planu utrzymania lokomotyw spalinowych serii SM42 eksploatowanych przez CTL Logistics Sp. z o.o. Praca nr M-8/160/2016/P, Politechnika Krakowska, Kraków, maj 2016. 
9. Optymalizacja planu utrzymania wagonów cystern typu 440Ra eksploatowanych przez CTL Logistics Sp. z o.o. Praca nr M-8/220/2016/P, Politechnika Krakowska, Kraków, maj 2016.

10. Optymalizacja planu utrzymania wagonów samowyładowczych typu 418V własności CTL Maczki-Bór S.A. Praca nr M-8/543/2017/P, Politechnika Krakowska, Kraków, czerwiec 2017.

11. PN-EN 50126-1:2018-02 Zastosowania kolejowe - Specyfikowanie i wykazywanie niezawodności, dostępności, podatności utrzymaniowej i bezpieczeństwa (RAMS) Część 1: Proces ogólny RAMS.

12. PN-EN 50129:2007 Zastosowania kolejowe - Systemy łączności, przetwarzania danych i sterowania ruchem - Elektroniczne systemy sterowania ruchem związane $\mathrm{z}$ bezpieczeństwem.

13. PN-EN 61508 (seria) Bezpieczeństwo funkcjonalne elektrycznych /elektronicznych/ programowalnych elektronicznych systemów związanych z bezpieczeństwem.

14. Rozporządzenie Wykonawcze Komisji Europejskiej (UE) nr 402/2013 z dnia 30 kwietnia 2013 r. w sprawie wspólnej metody oceny bezpieczeństwa w zakresie wyceny i oceny ryzyka i uchylające rozporządzenie (WE) nr 352/2009 (Dz. U. UE L121 z 03.05.2013).

15. Smith D. J.: Reliability, Maintainability and Risk: Practical Methods for Engineers, 8th edition. Butterworth-Heinemann, 2011.

16. Stapelberg R. F.: Handbook of reliability, availability, maintainability and safety in engineering design. Springer Science \& Business Media, 2009.

17. Szkoda M., Kaczor G.: RAMS analysis of railway vehicles' lifecycle. Journal of KONBiN, vol. 41, 2017.

18. Szkoda M.: Kształtowanie potencjału przewozowego przedsiębiorstw transportu kolejowego. Monografia. Wydawnictwo Politechniki Krakowskiej, Kraków 2017, ISBN: 978-83-7242-925-4.

19. Szkoda M., Satora M.: Change in the maintenance strategy as a method of improving the efficiency of the process of operation of railway means of transport. MATEC Web of Conferences, 234/2018.

20. Szopa T.: Niezawodność i bezpieczeństwo. Oficyna Wydawnicza Politechniki Warszawskiej, Warszawa 2009. 